\title{
Who Revolts? Empirically Revisiting the Social Origins of Democracy
}

\author{
Sirianne Dahlum ${ }^{1}$, Carl Henrik Knutsen ${ }^{2}$, and Tore Wig ${ }^{3}$ \\ 1 sirianne.dahlum@v-dem.net, V-Dem Institute, University of Gothenburg \\ ${ }^{2}$ c.h.knutsen@stv.uio.no, Department of Political Science, University of Oslo \\ 3 tore.wig@stv.uio.no, Department of Political Science, University of Oslo
}

July 19, 2018 


\begin{abstract}
Several prominent accounts suggest that democratic transitions are more likely to take place when opposition to the incumbent regime is led by certain social groups. We further develop the argument that opposition movements dominated by industrial workers or the urban middle classes have both the requisite motivation and capacity to bring about democratization. To systematically test this argument, we collect new data on the social composition of anti-regime opposition movements, globally from 1900-2006. We find that movements dominated by one of these urban groups more often result in democracy, both when compared to other movements and to situations without organized mass opposition. As expected, the relationship is stronger in urban than rural societies, and in more recent decades. When further differentiating the groups and accounting for plausible alternative explanations, the relationship between industrial worker campaigns and democratization is very robust, whereas the evidence is mixed for middle class campaigns.
\end{abstract}

Keywords: Democratization, revolution, mass mobilization, protest

The supplementary materials for this study is available in the online appendix. Replication files are available in the JOPData Archive on Dataverse (http://thedata.harvard.edu/dvn/dv/jop). This research was funded by the Research Council Norway, "Young Research Talent" grant, pnr 240505, PI: Carl Henrik Knutsen, but also by a “2016 Småforsk Grant” from the Department of Political Science, University of Oslo, PI: Carl Henrik Knutsen, and by Riksbankens Jubileumsfond, Grant M13-0559:1, PI: Staffan I. Lindberg, V-Dem Institute, University of Gothenburg, Sweden. 
Democratic transitions often emerge after organized mass movements force incumbent regimes from power, either directly as revolutions or indirectly, for instance through extracting democratic concessions (Acemoglu and Robinson, 2006). Still, not all opposition movements engender democracy. Differences in opposition tactics and structural conditions can help explain some of this variation. But, who revolts should also matter. Certain social groups may be especially likely to achieve democratization when mobilizing against the regime, as suggested by many comparative social scientists and historians. While some hold that peasants - under certain conditions - are instrumental in democratic revolutions (e.g., Stephens, 1989), many scholars highlight the roles played by two urban groups - the urban middle classes and industrial workers.

Scholars part ways, however, when it comes to which urban group they consider more important for democratization.Moore (1966), for example, argues that revolutions involving the bourgeoisie lead to democracy. Studying a different (and broader) set of cases, Rueschemeyer, Stephens and Stephens (1992) and Collier (1999) hold that mobilized industrial workers, with their high organizational capacity, are the main agents of democratization. Despite these (and other) excellent country-case and small-n comparative studies, conclusions thus vary with the cases under scrutiny, raising questions about the generality of the reported relationships. Some large-n studies also speak indirectly to the issue. Ansell and Samuels (2014) posit that the urban middle class is the main agent of democratization, while Boix (2003) views "the poor" as the biggest threat to dictatorships. Yet, these treatments rely on distal proxies for the preferences and capacities of social groups, such as GDP per capita or income inequality. Likewise, large-n studies of franchise extensions that have followed revolutionary threats conjecture that industrial workers were key actors (Przeworski, 2009), but without using a direct measure of the worker-dominance of revolutions. Finally, work on non-violent conflict links opposition movement features to democratization, but focuses mainly on tactical choices and enabling structural conditions (Chenoweth and Stephan, 2011; Celestino Rivera and Gleditsch, 2013). Thus, direct (large-n) evidence that links the social composition of anti-regime movements to democratization is missing. 
We clarify how and why the social composition of opposition movements affects democratization. We expect that both the urban middle classes and, especially, industrial workers have the requisite motivation and capacity to engender democratization, at least in fairly urban and industrialized societies. Other social groups - even after mobilizing in opposition to the regime - often lack the capacity to sustain large-scale collective action or the motivation to pursue democracy. We collect data on social composition of opposition movements to test these expectations, measuring degree of participation of six major social groups in about 200 anti-regime campaigns globally from 1900-2006. Movements dominated by industrial workers or middle classes are more likely to yield democratization, particularly in fairly urbanized societies. Movements dominated by other groups, such as peasants or military personnel, are not conducive to democratization, even compared to situations without any opposition mobilization. When separating the groups, results are more robust for industrial worker campaigns, corroborating the accounts by Rueschemeyer, Stephens and Stephens (1992) and Collier (1999).

\section{Argument}

We posit that a group's potential for achieving democracy through mass mobilization hinges on the presence of two features. First, protesters must be motivated to confront the incumbent regime and push for democracy. Second, they must have access to resources that provide strategic leverage over the regime and that enable sustained large-scale collective action. Our argument is combinatorial: both motivation and capacity are needed to achieve democratization. While differing, e.g., in their specific sources of organizational capacity and leverage, we propose that both urban middle class groups and industrial workers exhibit this combination.

Regarding motivation, social groups may prefer democratization if they anticipate more favorable policies under a new democracy. Relatively poor but numerically strong groups supposedly favor democratization, since democracy allows them to win elections and subsequently legislate redistributive policies (Acemoglu and Robinson, 2006; Boix, 2003). The logic holds even if we relax the strong assumption (see Ansell and Samuels, 2014) that redistribution is the key motivation: If we assume, first, that individuals with similar socioeconomic features (occupation, education, income, etc.) are more likely to hold converging preferences also over other 
policies (family policies, work regulations, etc.) and, second, that numerical strength yields electoral success, larger social groups should more strongly prefer democracy. Anticipated numerical strength also matters; groups that expect to be electorally important in the future may prefer democracy, even if weak now, if they have sufficiently long time horizons. Hence, industrial workers and middle classes should favor democracy, both in urbanized, industrial societies, and in countries where these processes are on the horizon. Conversely, in rural, less industrialized contexts rural laborers might rationally support democracy, but not necessarily if they expect future urbanization. Less numerous and wealthier groups, such as landowners or military officers, should not support democracy according to this logic.

The capacities of protestors are found in their leverage and in their abilities to co-ordinate and maintain large-scale collective action. Leverage comes from the power resources that a group can draw on to inflict various costs on the autocratic regime, and thus use to extract concessions, including political liberalization. Leverage can relate to imposition of economic costs on the regime, through measures such as moving capital assets abroad or carrying out strikes in vital sectors. Other sources of leverage include access to weapons, manpower with relevant training, and militant ideologies that motivate recruits. Urban middle classes score fairly high on leverage in many societies. Many urban professionals occupy inflection points in the economy, such as finance. Industrial workers can also hold a strategic stranglehold over the economy, being able to organize nationwide or localized strikes targeting key sources of revenue for the regime. In addition, workers often have fairly high military potential, due to military experience (often the case with mass conscription) and, historically, often being related to revolutionary, sometimes violence-condoning, ideologies (Hobsbawm, 1974).

Riots and uprisings are often fleeting, and opposition movements are therefore more frequent than regime changes. Hence, in addition to leverage, protestors must be able to organize and maintain large-scale collective action over time, also after an initial uprising, in order to challenge the regime. In this regard, groups with permanent, streamlined organizations can effectively transmit information, monitor participants, and disperse side-payments. Organizations also help with recruiting new individuals, networking with foreign actors, and experi- 
menting with and learning effective tactics. The urban middle classes have some potent assets in this regard, as they include members with high human capital, which might enhance organizational skills. Various civil society-, student-, and professional organizations can help mobilize at least parts of the middle classes. Industrial workers typically score very high on organizational capacity (see Collier, 1999; Rueschemeyer, Stephens and Stephens, 1992). They are often organized in long-standing and comprehensive unions and labor parties, and have extensive networks, including international labor organizations and the Socialist International. In sum, we expect opposition movements dominated by the middle classes or industrial workers to be related to subsequent democratization. Yet, we anticipate a clearer relationship for industrial worker campaigns, due to their multiple sources of leverage and especially strong organizational capacity allowing for effective and sustained challenges to the regime.

\section{Data and analysis}

We consider all anti-regime campaigns registered in NAVCO - a global dataset describing violent and non-violent mass opposition campaigns, 1900-2006 (Chenoweth and Lewis, 2013). NAVCO movements have a discernible leadership, at least 1000 participants, and a coherent organization - identified to aim for regime change or "other goals" (e.g., policy concessions, removal of leader, political liberalization). We exclude NAVCO's "secessionist movements". We code social group profiles for 193 campaigns, leaving 10 relevant cases missing due to no/too uncertain information. Sources include Swarthmore (2015), Ness (2015), and country-specific secondary sources. Our core categories are: peasants; public sector employees; military; religious or ethnic groups; industrial workers; urban middle classes (see Appx. A). For each group, we code three dummies. First, participating is scored 1 if the group is mentioned as participants in at least two separate sources. A 0-score means that a group's presence was too small to be recognized by the sources. Second, we code whether a movement originated among the group. Third, we code whether the movement is dominated by the group. This obtains when a group makes up a majority of campaign members or if it, according to the sources, was highly influential for the movement. While the latter requires subjective evaluation, we specified procedures to streamline coding decisions, and set a high threshold for being considered "highly 
influential". Our coders (RAs) explicitly assessed their degree of certainty for each coding.

We focus here on Industrial workers and Urban middle classes. The former refers to labor employed in manufacturing and mining. The latter category is harder to delineate, but we include business elites, smaller merchants, professionals (lawyers, doctors, etc), and students (see Appx. J for more disaggregated tests). We treat public sector employees as a separate group. Their tighter relationship with the state, and thus often the government, means that their motivation to instigate regime change may be different. While frequencies have fluctuated over time, industrial workers participated in $62 \%$ of campaigns, overall, whereas the urban middle classes participated in $79 \%$. About $1 / 5$ of campaigns were dominated by urban middle classes, and likewise for industrial workers (note that some campaigns do not have a dominating group). To illustrate the coding scheme, the Czechoslovakian 1989 Velvet Revolution is described as a broad-based movement consisting of urban middle classes, industrial workers, and peasants. All three groups are thus registered as participating. According to, e.g., Swarthmore, the movement was sparked by student demonstrations on International Students Day. Swarthmore further describes the organization Public Against Violence, made up of, e.g., artists, scientists and intellectuals, as the "leading force". The movement is thus coded as originating in and dominated by urban middle classes. To assess inter-coder reliability, around 10\% of cases (21/203) were double-coded, and the overlap was generally high (Appx. E).

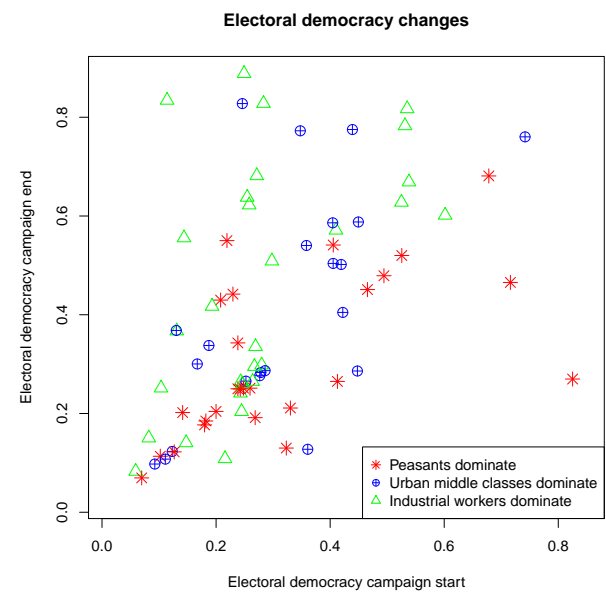

Figure 1: Campaigns dominated by industrial workers, urban middle classes, and peasants, with Polyarchy scores measured at campaign start-year (X-axis) and end-year (Y-axis)

For our dependent variable (DV), we draw on two measures of (electoral) democracy. First, the 
binary measure from Boix, Miller and Rosato (2013) (BMR) requires "free and fair" elections and that $1 / 4$ of citizens are enfranchised for coding a regime as democratic. Our main measure, however, allows us to also capture more incremental changes: Polyarchy from V-Dem (Coppedge et al., 2016a) is continuous and ranges from 0-1 (0.01-0.95 in the data). It includes indicators on whether the chief executive is elected (directly or indirectly), clean elections, freedoms of association and speech, and suffrage extension.

Figure 1 shows pre- and post-campaign levels of Polyarchy for campaigns dominated by different groups. Most middle class- and worker-dominated campaigns are associated either with no change (on diagonal) or democratic improvements (above diagonal). In contrast, peasant-dominated campaigns are often succeeded by democratic backsliding.

We also ran regressions using campaigns as units, measuring change in democracy from campaign start to one (or more) years after the campaign ended, controlling for country- and campaign-level covariates (Appx. E). Urban campaigns are more often followed by democratization than other campaigns, but the relationship is clearer for industrial worker- than middle class campaigns. Yet, these cross-section models exclude information from observations without campaigns, disallowing comparisons between specific campaigns and situations where no campaign exists. Further, controlling for country- and year-fixed effects is infeasible in this set-up. Country-specific features related to geography or political culture, for example, might influence the motivations and capacities of different groups and democratization. Hence, we use a country-year setup and estimate the following OLS specification:

$D E M_{i, t+1}=\beta_{0}+\beta_{1} I W_{i, t}+\beta_{2} M C_{i, t}+\beta_{3} O C_{i, t}+\beta_{4} D E M_{i, t}+\mu \mathbf{X}_{i, t}+\zeta_{i}+\theta_{t}+\epsilon_{i, t}$ $D E M_{i, t+1}$ is democracy in year $t+1$ in country $i . I W$ and $M C$ register ongoing campaigns dominated by, respectively, industrial workers and urban middle classes. Alternatively, we use a combined $U G$ (Urban group) dummy. $O C$ registers other campaigns, where other groups dominate or where no group clearly dominates. Hence, the reference category is no ongoing campaign. We include as regressors democracy at $t\left(D E M_{i, t}\right)$, a vector of covariates $\left(\mathbf{X}_{i, t}\right)$, and country- $\left(\zeta_{i}\right)$ and year-fixed effects $\left(\theta_{t}\right)$. Errors are clustered by country.

Table 1 presents two versions of our benchmark controlling for urbanization, income and 
population. It includes 9099 observations from 1900-2006 for 147 countries. Model 1 uses the cruder $U G$ and Model $2 I W$ and $M C$. Following Model 1, a campaign dominated by one of the urban groups increases Polyarchy in $t+1$ by 0.04 compared to when there is no ongoing campaign, and $U G$ is highly significant. $U G$ campaigns are also positively related to democratization compared to other campaigns (the short-term effect is $U G-O C=0.04$ ). In Model 2, $I W$ is significant at $1 \%$ and larger than $U G$ in Model 1 , whereas $M C$ is smaller and insignificant. Regarding the estimated short-term effect, Polyarchy increases by about 0.05 in $t+1$ given an IW campaign in $t$, comparable to the change in Ukraine from the start of the Orange Revolution to the year after it finished (0.05). IW-OC is also positive and highly significant, whereas $M C-O C$ is insignificant at conventional levels.

Results are similar for change in Polyarchy (from $t$ to $t+1$ ) as dependent variable (Model 3), and even clearer when considering only "democratic upturns" (following Teorell, 2010) in Model 4. Here, $I W$ remains highly significant, whereas $M C$ turns weakly significant $(t=$ 1.90). Yet, $M C-O C$ remains insignificant. Model 5 is a logit model using BMR and only including autocratic observations in $t$. This reduces variation in the DV; only 102 democratization episodes are included, and we exclude country-fixed effects (if included, only 68 countries inform estimates). In this model, neither $I W$ nor $M C$ are clearly distinguishable from $O C$, but both are significant at $5 \%$ compared to situations with no campaigns.

We report alternative tests in the Appendices. We use our inter-coder reliability tests to estimate measurement error and run Errors-in-Regression models (Appx. G). This strengthens results, though only $I W$ is robust. Other tests also find that only $I W$ is robust (see Appx. F). These include measuring democracy $5 / 10$ years after campaigns (we find a stronger longterm than short-term effect of $I W$ ), omitting controls, and adding controls such as civil war, violent/non-violent campaign tactics, campaign size, or number of participating groups. $I W$ is robust and $M C$ is strengthened when including public employees as part of $M C$ or employing lexical scales coding the level of group participation in campaigns. We estimate controlled direct effects, holding proxies of regime strategies towards opposition groups constant, with sequential G-estimation (Appx. H). These results overall suggest a positive effect from both 
Table 1: Core cross-section times series models

\begin{tabular}{|c|c|c|c|c|c|}
\hline Model & (1) & (2) & (3) & $(4)$ & $(5)$ \\
\hline Estimator & FE OLS & FE OLS & FE OLS & FE OLS & Logit \\
\hline Dependent variable & \multicolumn{2}{|c|}{ V-Dem Polyarchy } & $\Delta$ Polyarchy & $+\Delta$ Polyarchy & BMR democratiz. \\
\hline Ind. wor. OR mid. cl. dominate (UG) & $\begin{array}{c}0.040 * * * \\
(3.06)\end{array}$ & & & & \\
\hline Industrial workers dominate (IW) & & $\begin{array}{c}0.054 * * * \\
(2.84)\end{array}$ & $\begin{array}{c}0.054 * * * \\
(2.84)\end{array}$ & $\begin{array}{c}0.047 * * * \\
(2.82)\end{array}$ & $\begin{array}{c}1.085^{* *} \\
(2.53)\end{array}$ \\
\hline Middle classes dominate (MC) & & $\begin{array}{l}0.023 \\
(1.27)\end{array}$ & $\begin{array}{l}0.023 \\
(1.27)\end{array}$ & $\begin{array}{c}0.029 * \\
(1.90)\end{array}$ & $\begin{array}{c}1.289 * * * \\
(3.16)\end{array}$ \\
\hline Other campaign (OC) & $\begin{array}{l}-0.002 \\
(-0.57)\end{array}$ & $\begin{array}{l}-0.003 \\
(-0.84)\end{array}$ & $\begin{array}{l}-0.003 \\
(-0.84)\end{array}$ & $\begin{array}{c}0.006 * * \\
(2.03)\end{array}$ & $\begin{array}{c}0.736^{* *} \\
(2.09)\end{array}$ \\
\hline Ln GDP per capita & $\begin{array}{l}0.001 \\
(0.38)\end{array}$ & $\begin{array}{l}0.001 \\
(0.30)\end{array}$ & $\begin{array}{l}0.001 \\
(0.30)\end{array}$ & $\begin{array}{l}-0.002 \\
(-0.55)\end{array}$ & $\begin{array}{c}0.396^{*} \\
(1.74)\end{array}$ \\
\hline Ln population & $\begin{array}{l}-0.001 \\
(-0.58)\end{array}$ & $\begin{array}{l}-0.001 \\
(-0.46)\end{array}$ & $\begin{array}{l}-0.001 \\
(-0.46)\end{array}$ & $\begin{array}{l}0.003 \\
(1.05)\end{array}$ & $\begin{array}{l}0.002 \\
(0.03)\end{array}$ \\
\hline Urbanization & $\begin{array}{c}0.025 * * \\
(2.23)\end{array}$ & $\begin{array}{c}0.024 * * \\
(2.22)\end{array}$ & $\begin{array}{c}0.024 * * \\
(2.22)\end{array}$ & $\begin{array}{c}0.023^{* *} * \\
(2.10)\end{array}$ & $\begin{array}{l}0.228 \\
(0.27)\end{array}$ \\
\hline Lagged Polyarchy & $\begin{array}{c}0.949 * * * \\
(169.46)\end{array}$ & $\begin{array}{c}0.950 * * * \\
(172.86)\end{array}$ & $\begin{array}{c}-0.050 * * * \\
(-9.18)\end{array}$ & $\begin{array}{c}-0.035^{* * *} * \\
(-7.52)\end{array}$ & \\
\hline Country dummies & $\mathrm{Y}$ & $\mathrm{Y}$ & $\mathrm{Y}$ & $\mathrm{Y}$ & $\mathrm{N}$ \\
\hline Year dummies & $\mathrm{Y}$ & $\mathrm{Y}$ & $\mathrm{Y}$ & $\mathrm{Y}$ & $\mathrm{Y}$ \\
\hline$U G-O C, \mathrm{t}$-value & $0.042,2.89$ & & & & \\
\hline$I W-O C, \mathrm{t}$-value & & $0.057,2.76$ & $0.057,2.76$ & $0.042,2.31$ & $0.349,0.50$ \\
\hline$M C-O C, \mathrm{t}$-value & & $0.026,1.42$ & $0.026,1.42$ & $0.023,1.47$ & $0.553,0.91$ \\
\hline$I W-M C, \mathrm{t}$-value & & $0.030,0.94$ & $0.030,0.94$ & $0.019,0.70$ & $-0.204,-0.33$ \\
\hline $\mathrm{N}$ & 9099 & 9099 & 9099 & 9099 & 4705 \\
\hline $\mathrm{R}^{2} /$ Pseudo $\mathrm{R}^{2}$ & 0.939 & 0.939 & 0.087 & 0.105 & 0.061 \\
\hline Countries & 147 & 147 & 147 & 147 & 121 \\
\hline
\end{tabular}

$I W$ and $M C$. Yet, urban groups could "bandwagon" on ongoing campaigns anticipated to lead to successful democratization, whereas, e.g., peasants might be attracted to rural guerrilla campaigns that are less conducive to democratization (but, see Appx. J). Thus, we estimate IV models that endogenize the social profiles of campaigns. We discuss and assess the validity of our instruments, which draw on profiles of opposition campaigns in other countries in the region, in Appx. I. These results suggest that both $I W$ and $M C$ enhance democratization. Finally, we assess context-sensitivity (Appx. K). The findings for $I W$ (and $U G$ ) hold up when removing data from any region ( $M C$ is only significant when removing Latin America). The relationships are stronger in later decades and, as anticipated, in more urbanized societies.

\section{Conclusion}

We have discussed how opposition movements dominated by industrial workers and urban middle classes may be both motivated and able to pursue democratization. Using original data on the social groups partaking in opposition campaigns globally from 1900-2006, we find that movements dominated by these urban groups are linked to democratization, both when com- 
pared to movements dominated by other groups and to situations when no organized opposition movement exists. While apparent in different contexts, the relationship is stronger in more recent decades and in urbanized societies. When separating between middle classes and industrial workers, we find more robust support for the democratizing role of worker movements. Overall, our results thus corroborate the accounts presented by Rueschemeyer et al. (1992) and Collier (1999) - industrial workers are key agents of democratization.

Explaining the sensitivity of the middle class result may be a fruitful area for further inquiry. For example, "urban middle classes" is a heterogeneous category, and certain sub-groups may be more conducive to democratization than others. In Appx. J we report results suggesting that opposition movements dominated by students and educated professionals are related to democratization, but not other middle class movements. Also, tests in Appx. J suggest that middle class campaigns, in contrast to worker campaigns, may only be effective when choosing non-violent tactics. These more nuanced propositions warrant further scrutiny.

Our findings inform different literatures. We provide a novel empirical take on the social origins of democratic revolutions, thus contributing to long-standing debates in comparativehistorical political sociology (Moore, 1966; Luebbert, 1991; Rueschemeyer, Stephens and Stephens, 1992), but also inform the more recent literature on the economic origins of democracy (Acemoglu and Robinson, 2006; Boix, 2003; Ansell and Samuels, 2014). Finally, we add to the rapidly growing literature on the failures and successes of opposition movements (e.g., Chenoweth and Stephan, 2011), by linking the outcomes of these movements to their social composition.

\section{References}

Acemoglu, Daron and James A. Robinson. 2006. Economic Origins of Dictatorship and Democracy. New York: Cambridge University Press.

Ansell, Ben W and David J Samuels. 2014. Inequality and Democratization. Cambridge: Cambridge University Press.

Boix, Carles. 2003. Democracy and Redistribution. Cambridge: Cambridge University Press. Boix, Carles, Michael Miller and Sebastian Rosato. 2013. "A complete data set of political 
regimes, 1800-2007." Comparative Political Studies 46(12):1523-1554.

Celestino Rivera, Mauricio and Kristian Skrede Gleditsch. 2013. "Fresh carnations or all thorn, no rose? Nonviolent campaigns and transitions in autocracies." Journal of Peace Research 50(3):385-400.

Chenoweth, Erica and Maria J. Stephan. 2011. Why Civil Resistance Works: The Strategic Logic of Nonviolent Conflict. New York: Columbia University Press.

Chenoweth, Erica and Orion A. Lewis. 2013. "Unpacking nonviolent campaigns. Introducing the NAVCO 2.0 dataset." Journal of Peace Research 50(3):415-423.

Collier, Ruth Berins. 1999. Paths Towards Democracy: The Working Class and Elites in Western Europe and South America. Cambridge: Cambridge University Press.

Coppedge, Michael, John Gerring, Staffan I Lindberg, Svend-Erik Skaaning, Jan Teorell, David Altman, Michael Bernhard, M Steven Fish, Adam Glynn, Allen Hicken, Carl Henrik Knutsen, Kelly McMann, Valeriya Mechkova, Farhad Miri, Pamela Paxton, Daniel Pemstein, Rachel Sigman, Jeffrey Staton and Brigitte Zimmerman. 2016. "V-Dem Country-Year Dataset v6.1." Varieties of Democracy Project.

Hobsbawm, Eric. 1974. "Labor history and ideology." Journal of Social History 7(4):371-381. Luebbert, Gregory M. 1991. Liberalism, Fascism, or Social Democracy: Social Classes and the Political Origins of Regimes in Interwar Europe. Oxford: Oxford University Press.

Moore, Barrington. 1966. Social Origins of Democracy and Dictatorship: Lord and Peasant in the Making of the Modern World. Boston: Beacon Press.

Ness, Immanuel. 2015. "The International Encyclopedia of Revolution and Protest".

URL: http://www.revolutionprotestencyclopedia.com

Przeworski, Adam. 2009. "Conquered or granted? A history of suffrage extensions." British Journal of Political Science 39(2):291-321.

Rueschemeyer, Dietrich, Evelyne Huber Stephens and John D. Stephens. 1992. Capitalist Development and Democracy. Chicago: University of Chicago Press.

Stephens, John D. 1989. "Democratic Transition and Breakdown in Western Europe, 18701939: A Test of the Moore Thesis." American Journal of Sociology 94(5):1019-1077. 
Swarthmore. 2015. "Global Nonviolent Action Database".

URL: http://nvdatabase.swarthmore.edu

Teorell, Jan. 2010. Determinants of Democracy: Explaining Regime Change in the World, 1972-2006. Cambridge: Cambridge University Press. 


\section{Author biographies}

Sirianne Dahlum is a Senior Researcher at the Peace Research Institute Oslo, PRIO, Oslo, Norway.

Carl Henrik Knutsen is a Professor at the Department of Political Science, University of Oslo, Oslo, Norway.

Tore Wig is an Associate Professor at the Department of Political Science, University of Oslo, Oslo, Norway.

\section{Acknowledgments}

We would like to thank the following people for comments, in no particular order: Michael Bernhard, Scott Gates, Håvard Strand, Kristian Gleditsch, Håvard Nygård, Marianne Dahl, Adam Glynn, Magnus B. Rasmussen, Svend-Erik Skaaning, Holger Lutz Kern, Jonathan Chapman, Henning Finseraas, Charles Butcher, Carsten Jensen, David Cingranelli, Haakon Gjerløw, Phillip Keefer, Beth Simmons, John Gerring, Kyle Marquardt, and Lucas Leeman. We would also like to thank participants at the Conflict and Democratization workshop at Aarhus University, the Annual V-DEM conference 2017, the panel "Protest and Revolt" at the 2016 Annual EPSA conference, the panel "Mass Public and Elite Preferences for Democracy" at the 2016 MPSA conference, the panel "Contention Inequality and Democratization" at the 2016 Annual APSA Meeting, the workshop "New Perspectives on Institutional Change" at LIEPP, Science Po, Paris, the workshop "Securing the Victory: From initial campaign success to consolidated democracy" at PRIO in 2016, as well as at a 2016 Tuesday Seminar at the Department of Political Science, University of Oslo. 